\title{
Damaging events along roads during bad weather periods: a case study in Calabria (Italy)
}

\author{
O. Petrucci and A. A. Pasqua \\ CNR-IRPI, U.O.S. of Cosenza - Via Cavour 4/6, Rende (Cosenza), Italy \\ Correspondence to: O. Petrucci (o.petrucci@irpi.cnr.it)
}

Received: 26 April 2011 - Revised: 19 December 2011 - Accepted: 21 December 2011 - Published: 17 February 2012

\begin{abstract}
The study focuses on circumstances that affect people during periods of bad weather conditions characterised by winds, rainfall, landslides, flooding, and storm surges. A methodological approach and its application to a study area in southern Italy are presented here. A 10-yr database was generated by mining data from a newspaper. Damaging agents were sorted into five types: flood, urban flooding, landslide, wind, and storm surge. Damage to people occurred in 126 cases, causing 13 victims, 129 injured and about 782 people involved but not injured.
\end{abstract}

For cases of floods, urban flooding and landslides, the analysis does not highlight straightforward relationships between rainfall and damage to people, even if the events showed different features according to the months of occurrence. The events occurring between May and October were characterised by concentrated and intense rainfall, and between May and July, the highest values of hourly $(103 \mathrm{~mm}$ on the average) and monthly rainfall $(114 \mathrm{~mm}$ on the average) were recorded. Urban flooding and flash floods were the most common damaging agents: injured, involved people and more rarely, cases with victims were reported.

Between November and April, the highest number of events was recorded. Rainfall presented longer durations and hourly and sub-hourly rainfall were lower than those recorded between May and October. Landslides were the most frequent damaging agents but the highest number of cases with victims, which occurred between November and January, were mainly related to floods and urban flooding.

Motorists represent the totality of the victims; $84 \%$ of the people were injured and the whole of people involved. All victims were men, and the average age was $43 \mathrm{yr}$. The primary cause of death was drowning caused by floods, and the second was trauma suffered in car accidents caused by urban flooding. The high number of motorists rescued in sub- merged cars reveals an underestimation of danger in the case of floods, often increased by the sense of security related to the familiarity of the road. In contrast, in the cases of people involved in landslides, when there was enough time to realise the potential risk, people behaved appropriately to avoid negative consequences. Of the victims, $50 \%$ were killed along fast-flowing roads; this may be related to the high speed limit in force on these roads, as a car's speed reduces the reaction time of a driver's response to an unexpected situation, whatever the damaging agent is. These results can be used in local information/education campaigns to both increase risk awareness and promote self-protective behaviours.

Moreover, the mapping of damaging effects pointed out the regional sectors in which the high frequency of the events suggests further planning of in-depth examinations, which can individuate the critical points and local regulator interventions that might change damage incidences in the future.

\section{Introduction}

Episodes of severe weather conditions that cause diffuse landslides and floods can be defined as Damaging Hydrogeological Events (DHEs) (Petrucci et al., 2008, 2010) and can result in both economic damage and human injury. Besides separate analyses of landslides or flood effects, approaches can be found in the literature that focus on the simultaneous occurrence of both types of phenomena (Crozier, 2005), especially those accounting for historical events (Barnikel and Becht, 2003; Copien et al., 2008) or risk assessment (Salvati et al., 2010).

During DHEs, damage can occur on roads as either static elements (the actual road) or dynamic elements (cars and pedestrians using the road). Direct damage includes the cost 
Table 1. Summary table of papers reported in references and describing floods damage to people.

\begin{tabular}{|c|c|c|c|c|c|c|c|}
\hline & Author & $\begin{array}{l}\text { Study } \\
\text { area }\end{array}$ & $\begin{array}{l}\text { Study } \\
\text { period }\end{array}$ & $\begin{array}{l}\text { Length of } \\
\text { study period }(y)\end{array}$ & $\begin{array}{l}\text { Number of victims/ } \\
\text { Number of years }\end{array}$ & $\begin{array}{l}\text { Data on } \\
\text { age of victims }\end{array}$ & $\begin{array}{l}\text { Death circumstances } \\
\text { related to floods }\end{array}$ \\
\hline 1 & Coates (1999) & Australia & 1788-1996 & 208 & 4.75 & - & $\begin{array}{l}1406 \text { victims: } 398 \text { crossing a } \\
\text { watercourse; } 143 \text { crossing at a } \\
\text { ford, culvert, bridge or road; } \\
118 \text { were in a car }\end{array}$ \\
\hline 2 & $\begin{array}{l}\text { FitzGerald } \\
\text { et al. (2010) }\end{array}$ & Australia & 1997-2008 & 11 & 3.18 & $\begin{array}{l}10 \text { to } 29 \text { and } \\
\text { over } 70 \mathrm{yr}\end{array}$ & $\begin{array}{l}35 \text { victims: } 29 \text { crossing water- } \\
\text { ways; } 6 \text { because of road col- } \\
\text { lapses }\end{array}$ \\
\hline 3 & $\begin{array}{l}\text { Maples and } \\
\text { Tiefenbacher (2009) }\end{array}$ & Texas & 1950-2004 & 54 & 4.00 & - & $\begin{array}{l}216 \text { deaths were caused by au- } \\
\text { tomobile immersion on flooded } \\
\text { roadways }\end{array}$ \\
\hline 4 & Rappaport (2000) & USA & 1970-1999 & 29 & 4.75 & - & $\begin{array}{l}138 \text { victims reportedly died in, } \\
\text { or attempting to abandon, their } \\
\text { vehicles }\end{array}$ \\
\hline 5 & Ruin et al. (2008) & France & 2002 & - & - & 43 (mean) & $\begin{array}{l}23 \text { victims in a flash flood: } \\
4 \text { were drivers outside cars; } \\
1 \text { was a driver inside a car }\end{array}$ \\
\hline 6 & $\begin{array}{l}\text { Jonkman and } \\
\text { Vrijling (2008) }\end{array}$ & World & 1975-2002 & 27 & 9.14 & $\begin{array}{l}\text { Youngest and } \\
\text { oldest people }\end{array}$ & $\begin{array}{l}247 \text { victims: } 62 \text { as pedestrian; } \\
81 \text { people in vehicles }\end{array}$ \\
\hline
\end{tabular}

for restoration of infrastructure and damage to vehicles and people. Indirect damage affects society by disrupting utility services and local businesses, thereby incurring loss of revenue and tourism (Van Westen et al., 2006) as well as expenses resulting from driving longer distances because of road blockage (Zêzere et al., 2007). The vulnerability of roads during DHEs depends on both the characteristics of terrains along road tracks (at the presence of landslides and river crossings) and road design criteria (as the slope angle increases by excavations, removal of slope support in road cuts, alteration of surface runoff paths, and increases in either the depth or rates of runoff). The vulnerability of people moving along roads during DHEs essentially depends on the type of damaging agent they have to cope with, its speed and magnitude, and their mental alertness.

The literature concerning the effects of floods shows that drivers and pedestrians represent a high percentage of flood victims (Table 1). The losses of life are influenced by behaviour and individual vulnerability factors (Jonkman and Vrijling, 2008). Males seem to be highly vulnerable to dying in floods, even if the percentages assessed by different authors are different: figures range from $58 \%$ (Maples and Tiefenbacher, 2009), to $70 \%$ (Jonkman and Vrijling, 2008) or $71 \%$ (FitzGerald et al., 2010). This can be due to both the high involvement of males in driving and the high proportion of males' risk-taking behaviour (Jonkman and Kelman, 2005). Human behaviour, in fact, contributes to flood fatality occurrences (Ashley and Ashley, 2008), as people tend to deliberately drive through flooded roads, even underestimating warnings (Drobot et al., 2007). Factors leading to fatalities are: (1) improved safety of automobiles leading to a wrong belief of motorist invulnerability; (2) neglecting risks associated with flooded roadways including ignoring warnings and traffic-safety barriers; and (3) roadway familiarity, based on the proximity of the flooded road to either the driver's home or place of employment, which seems to increase the drivers' attempts to surmount water rushing across a road (Maples and Tiefenbacher, 2009). Also, the estimate average age of victims can be different from case to case, but it seems that youngest and oldest people are more frequently affected (FitzGerald et al., 2010; Jonkman and Vrijling, 2008).

Concerning wind effects, a number of studies have been reported. Ashley and Black (2008), for example, compiled a database for the period 1980-2005 to assess the threat to life in the conterminous United States from non-convective, high-wind events, and they concluded that $68 \%$ of wind fatalities occur in vehicles or boats; but in these cases, no hazardous behaviours were reported.

Landslides can induce severe road damage (Irigaray et al., 2000), and injuries or deaths can occur as a result of the following: (a) vehicles running into landslides; (b) vehicles being hit by landslides; (c) vehicles involved in collisions while swerving to avoid landslides; and (d) vehicles running into voids created by landslides (Wilson et al., 2005). Vehicle vulnerability depends on many factors, including the following: (a) the type and size of the landslide; (b) the type of infrastructure; (c) the speed and type of vehicle (Jaiswal et al., 2010); (d) the traffic volume; (e) the length of the landslide risk section of the route; (f) the number of occupants in the car (Budetta, 2002); and (g) alertness. In several regions, all these factors are difficult to quantify due to the scarcity of both damage records and data concerning 
traffic. Quantitative analyses can be performed by deterministic methods on limited road sectors for which data concerning both road characteristics and traffic volumes are available. One example, at a local scale, is shown by Jaiswal et al. (2010), who performed quantitative risk estimation for four elements at risk (railway tracks, vehicles, commuters and roads) considered to be exposed to three types of landslides, characterised by both their magnitude and return period.

Resuming, the literature generally analyses the effects on people of a single type of phenomena (landslide or flood, more rarely wind); the effects of floods on human life have been more deeply studied, in terms of death circumstances, individual vulnerability, and behavioural factors leading to fatalities.

In the present work, a 10-yr database of DHEs that occurred in a region of southern Italy was used to underline both the circumstances leading to damage to people and the most affected sectors. The proposed approach presents two peculiarities: (a) it focuses on damage along roads not caused by a single damaging phenomena but by the whole of damaging agents characterising bad weather periods; (b) the approach was designed for cases in which data on damage affecting people are unavailable, mainly due to the lack of agencies collecting them and because of laws safeguarding the privacy of citizens.

The results can supply a regional framework for the most frequent damaging circumstances, their seasonality and recurrence throughout the study period, and the most affected sectors. The results can be used in public-information programs designed to improve the awareness of vulnerable communities of people using the road network (Solana and Kilburn, 2003; FitzGerald et al., 2010), and to plan specific measures aiming to mitigate damage in the most frequently affected places, according to both the types of phenomena and effects recorded in the past.

\section{Methodological approach}

Data excerpted from newspapers can be utilised to create an Excel damage database that compiles a record of damage to people during DHEs throughout a period characterised by data continuity.

Press archives, alone or in conjunction with other historical sources, are regularly used to collect data concerning DHEs. Newspaper data allow either investigation or complete information of past landslides (Cuesta et al., 1999; Devoli et al., 2007; Kuriakose et al., 2009), floods (Rappaport, 2000; Agasse, 2003; Maples and Tiefenbacher, 2009; Adhikari et al., 2010), or both types of phenomena (Hilker et al., 2009). Collected data allow either analysis of the evolution of societal hazard perception (Llasat et al., 2009) or the estimation of direct financial damage as well as fatalities and injured people (FitzGerald et al., 2010). However, some limitations must be taken into account:

1. Newspapers are a systematic, nontechnical data source. The articles are affected by the reporter's perspective and familiarity with phenomena (Boholm, 2009).

2. Information regarding the type of phenomena must be inferred by journalistic descriptions. Quantitative data on triggers (i.e. rain or wind intensity) are not provided because articles focus more on the effects (damage) and less on their causes.

3. The number of victims must be carefully checked: newspapers may provide changing figures until the end of rescue operations (Salvati et al., 2010).

4. Generally, the completeness of the data depends on both the occurrence and severity of the damage to people. In the severest cases, the exact number of involved people is reported (and so the gender, age, and often names of people involved), while expressions like many people or several people are used in cases in which damage to people was low or very low.

Despite these disadvantages, especially in countries where there are no public authorities collecting this type of damage data and data from reinsurance companies are not available, newspapers can be used as proxy data to establish a catalogue of damaging situations that can provide an indicator of the social impact of DHEs.

\subsection{Data gathering, quality and organising}

Damage caused by DHEs can be obtained by a systematic analysis of daily newspapers throughout the study period. The time required to select these articles depends on the type of archive from which the data have to be collected. The most time-consuming case concerns paper archives. In these cases, for each year, 365 daily editions had to be leafed through, and the results of data acquisition (photocopies, scannerisation or digital photos) had to be typed then. The easiest method is working with online newspaper databases, in which keyword searches can be performed and data can be acquired by a simple copy-and-paste procedure.

For each damaged road quoted in each article, a database record had to be set. Each record was then identified by the name of the road track damaged and the date in which damage occurred. Data duplications can be related to two factors: (a) most damaging cases can be described in several consecutive editions of the newspaper, and (b) a certain road track can be affected more than once through the study period. A careful inspection of the database aiming to eliminate possible duplications was necessary, and the inspection was be facilitated by sorting the records by date, and by road track name. 
When the number of people affected is supplied by using informal expressions such as "some" or "many people", individual interpretations of the meaning of these "frequency" words can contribute to the subjectivity of damage assessment (Blong, 2003). Two approaches can be used: (a) discard these data (introducing bias in the dataset), and (b) set up subjective (but systematic) translations of these words into rough numerical estimates. This latest approach supplies an estimate: whatever the numbers used to indicate the different expressions, the result is always an assessed value which is based on arbitrary starting assumptions, and not a "measured" value.

Then, the information extracted was separated into three sections named road identification, damaging agents, and damage to people.

The record identification section contains the fields that identify a record: record number, road name, road type, municipality, year, month, and day in which the event occurred; the damage description, which contains the article sections copied from the newspaper and damage reports, is also included. If, in addition to newspapers, further sources describing the event are available, these sources can be used to provide additional elements to enhance damage descriptions. The road type at a regional scale, based on its importance, can be classified as highway, state road, county road, and municipal road.

The Damaging Agents section identifies the agent that causes damage. For each record, an analysis of the damage description allows the occurrence of one of the following types of agents to be individuated (other damaging agents not listed in the following can be included in specific geological and climatic frameworks):

1. Flood. Damage is related to river discharge, which can span roads beside the river or impact bridges crossing it, sometimes opening cracks and crevices along the impacted road. Damage occurrence and its severity depend on both the water level and the rapidity of the flood increase. A determining factor is the perception of danger: an underestimation of either the rapidity or power of the water flow is the key factor in determining whether people will be injured.

2. Urban flooding. The term urban flooding is used to indicate the effects of rainfall on areas characterised by a lack of drainage. High intensity rain can cause flooding when the city sewage system and draining canals do not have the capacity to drain away the amounts of rain that are falling. Mud eroded by rain can further obstruct water elimination and can merge with water, resulting in a dangerous slippery mixture. In underpasses, the level of water can rise quickly, resulting in panic and physical damage to people trapped in cars. These effects may be similar to those of floods, but in these cases, the water does not spill from a riverbed; thus, no references to rivers are found in the articles.
3. Landslide. Landslides can cause a wide range of effects depending on their type, velocity, and size. The severity of damage to roads ranges from low (i.e. debris on the roadway) to very high (i.e. long sectors of roads completely destroyed). The effects on people depend on the landslide's rate and size and on several other factors (i.e. the possibility of avoiding impact with the landslide depending on both the visibility conditions and the alertness of the driver).

4. Wind. Wind can result in consequences ranging from traffic delays to traffic interruptions, and the associated effects can be dangerous. Cars in transit (or parked) can be slightly damaged or completely destroyed by windblown objects, and people can be seriously affected, either motorists or pedestrians.

5. Storm surge. This agent can affect both seafront roads and main roads located in close proximity to the sea. During storm surges, sea waves can flood roads with both mud and debris. In the severest cases, water pressure can even break parts of the road, causing crevices and resulting in traffic interruptions. People walking or driving on damaged roads can also be affected.

The "damage to people" section separates the information contained in each article into several fields. The severity level field can contain one of the following options: victims (high damage), injured (medium damage), and people involved but not injured (low damage). The following field contains the circumstances resulting in victims, injured or people involvement as extracted from the articles.

As a general rule, in the severest cases, the information about the number of people involved and injured is complete and precise. On the contrary, in less severe cases, the information about people involved but not injured (i.e. in a cars pile-up without injured) is supplied by using colloquial expressions (i.e. many people involved). Even data about the gender and age of people involved and the hour of the event are generally available for severest cases, but they are reported less systematically in cases in which persons are neither killed nor injured.

By selectively filtering records according to the various fields, both the frequency and seasonality of different occurrences can be obtained, and road network sectors along which people are most frequently/severely affected can be individuated and characterised in terms of both damaging circumstances and meteorological framework in which the damage occurred. Moreover, maps of the most frequently affected road tracks can be usefully combined with local road maintenance and design of future roads. 


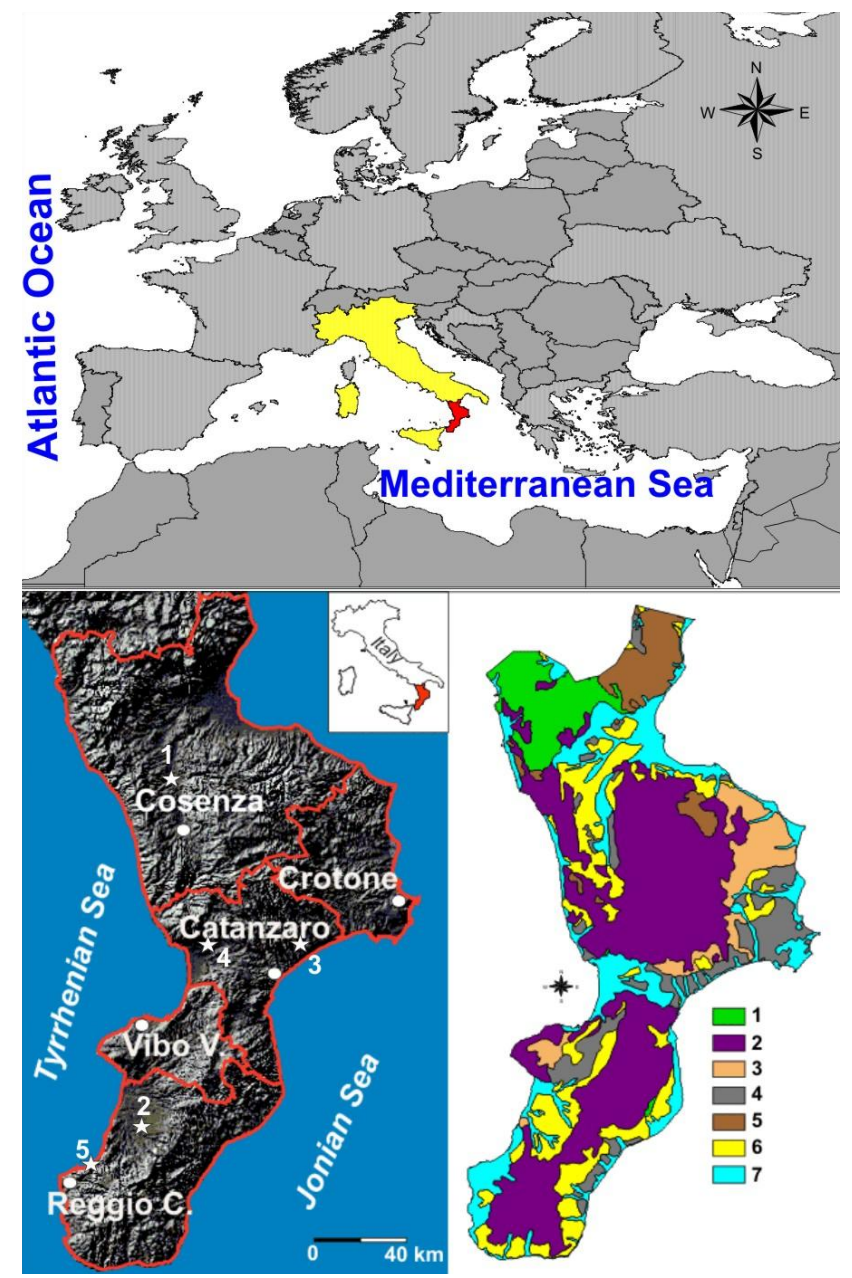

Fig. 1. Top: Mediterranean basin: Italy in yellow and Calabria in red. Bottom left: shaded relief map of Calabria and province boundaries (Abbreviations: Reggio Calabria = Reggio C.; Vibo Valentia = Vibo V.). White stars indicates some places quoted in Sect. 3 (1: Tarsia; 2: Taurianova; 3: Cropani; 4: Lametia Terme; 5: Scilla). Bottom right: simplified geological sketch of the region. Keys: (1) limestone and dolostone; (2) metamorphic and igneous rocks; (3) clays, marls and evaporitic rocks; (4) sandstones, marly clays and limestone marls; (5) flysch and clayey formations; (6) conglomerates, sands and sandstones; and (7) alluvial deposits.

\section{Application of the methodology to the Calabria region (Italy)}

Calabria $\left(15230 \mathrm{~km}^{2}\right)$ is the southernmost Italian peninsular region and is composed of allochthonous crystalline rocks (Palaeozoic to Jurassic) that were stacked over carbonate units during the middle Miocene. The region is characterised by an oblong shape. The mean altitude is $418 \mathrm{~m}$ a.s.l., and the maximum altitude is $2266 \mathrm{~m}$. (Fig. 1). The morphology is rough, and $90 \%$ of the territory is in relief. The other $10 \%$ consists of coastal and fluvial plains.

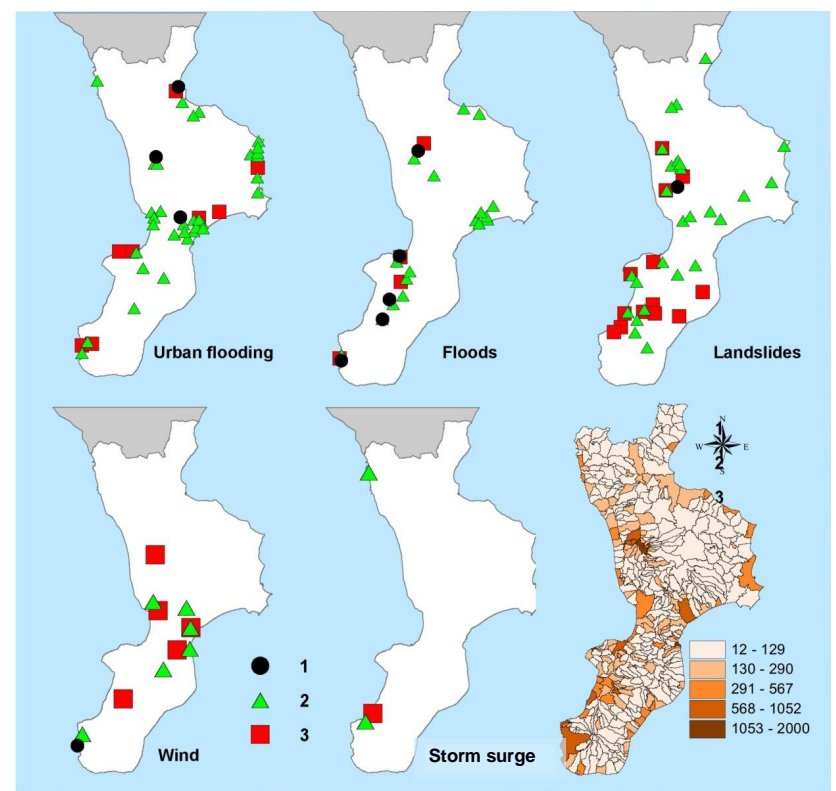

Fig. 2. Localisation of damage to people sorted according to the type of damaging agent. (1) Victims, (2) injured, and (3) involved people. The map on bottom-left represents the population density on a municipal scale (inhabitants per square kilometre).

The climate is Mediterranean, with dry summers and wet winters. The mean regional annual rainfall $(1151 \mathrm{~mm})$ is higher than the national value $(970 \mathrm{~mm})$. Due to the predominant west-to-east movement of meteorological perturbations, the rainiest area is the west side of the region, although the eastern sector is often hit by intense storms (Petrucci and Polemio, 2009). Climatic conditions and tectonic stresses deteriorate the rocks and predispose slopes to mass movements and erosion processes. During the autumn-winter period, DHEs causing economic damage and casualties are frequent (Petrucci and Versace, 2005, 2007; Petrucci et al., 2009).

The region is divided into five provinces (Cosenza, Catanzaro, Crotone, Vibo Valentia, and Reggio Calabria), further divided into 409 municipalities. The total number of inhabitants is 2009330 . The population density ranges from low values, characterising the innermost municipalities located on the reliefs, to high values typical of both the main towns and tourist cities located along the coasts (Fig. 2).

The road network comprises approximately 16000 kilometres of roads. The construction of the main roads started in the second half of the XIX Century, even if in 1906, only $1000 \mathrm{~km}$ of roads were finished. At the beginnings of the XX Century, the roads construction was pursued according to a simple geometry, made of two main coastal roads connected by some transversal roads linking east to west coast. This geometry is also the starting point of the current road network, which nowadays also presents a highway. The highway crosses the region from north to south, and the other roads are classified as state, county, and municipal roads. 
Table 2. Cases of damage resulting in victims. For each record, the following data are reported: damaging agent, number of victims, road type $(\mathrm{H}=$ Highway; $\mathrm{S}=$ State road; $\mathrm{C}=$ County road; and $\mathrm{M}=$ Municipal road), hour at which the damage occurred $(\mathrm{A}=$ afternoon), the sex of victim $(\mathrm{M}=$ male; $\mathrm{F}=$ female $)$, age of victim, and death circumstance.

\begin{tabular}{|c|c|c|c|c|c|c|c|c|c|}
\hline N. & $\begin{array}{l}\text { Damaging } \\
\text { agent }\end{array}$ & $\begin{array}{l}\text { N. of } \\
\text { victims }\end{array}$ & $\begin{array}{l}\text { Road } \\
\text { type }\end{array}$ & $\begin{array}{l}\text { Hour } \\
\text { LT }\end{array}$ & Sex & Age & Death circumstance & Tot. & $\%$ \\
\hline 1 & Urban flooding & 1 & S & A & M & 67 & \multirow{3}{*}{ Trauma: motorist died in a car accident } & \multirow{3}{*}{3} & \multirow{3}{*}{23} \\
\hline 2 & Urban flooding & 1 & $\mathrm{~S}$ & $\mathrm{~N}$ & M & 25 & & & \\
\hline 3 & Urban flooding & 1 & $S$ & 08:00 & M & 26 & & & \\
\hline 4 & Landslide & 2 & $\mathrm{H}$ & 21:00 & M & $27 ; 59$ & Trauma: motorist died in a car buried by a landslide & 2 & 15 \\
\hline 5 & Flood & 1 & $\mathrm{C}$ & A & M & 52 & \multirow{4}{*}{ Drowning: motorist died while trying to exit from a submerged car } & \multirow{4}{*}{6} & \multirow{4}{*}{46} \\
\hline 6 & Flood & 3 & $\mathrm{~S}$ & 10:00 & M & $1 ; 40 ; 44$ & & & \\
\hline 7 & Flood & 1 & M & A & M & 37 & & & \\
\hline 8 & Flood & 1 & $\mathrm{C}$ & 19:00 & M & 56 & & & \\
\hline 9 & Flood & 1 & M & 07:30 & M & 55 & Collapse affecting motorist rescued from flood & 1 & 8 \\
\hline \multirow[t]{2}{*}{10} & Wind & 1 & M & 12:00 & M & 76 & Collapse affecting motorist hit by objects driven by wind & 1 & 8 \\
\hline & & & & & & & Total & 13 & 100 \\
\hline
\end{tabular}

According to the different volumes of traffic, the age and the maintenance conditions, these roads are rather different, but they are all characterised by generally low standards. The highway is the only four-lane road in the region. Some state roads have stretches of two lanes, but not for the entire length. Excluding the highway, the width of the roads ranges from 22 (for some state roads) to $8.5 \mathrm{~m}$ (for municipal roads). The maintenance of the state roads is performed by a publically owned company, ANAS. The counties and municipalities maintain their parts of the network. Because of the lack of traffic monitoring gauges, only sporadic data of traffic volume are available for a few roads (http://www.stradeanas.it/).

Using the online archive of the main Calabrian newspaper (La Gazzetta del Sud), a Damage Database of DHEs in Calabria over a period of $10 \mathrm{yr}$ (1 January 2000-31 December 2009) was prepared. The study period was selected because of both the continuity of the newspaper data and the accuracy of articles describing damage due to an increasing awareness of human-climate interactions in recent years. We systematically analyzed day by day all the newspaper editions and we selected all the articles concerning the occurrence of damaging phenomena in the region, without applying any filtering criterion. The damage database contains 1913 records. Roads were damaged in $72 \%$ of these cases (1376 records), and 126 records (6.5\% of the total) reported the involvement of people.

\subsection{Data gathered}

Hereafter, the analysis will focus on the 126 records describing involvement of about 924 people, including 13 victims, 129 injured and about 782 people involved but not injured.

Victims were reported in 10 records (8\%) (Table 2), and they were all motorists: the majority died from drowning caused by floods $(46 \%)$ or trauma suffered in car accidents caused by urban flooding (23\%). Only one fatality was caused by trauma related to landslides, and circulatory collapse affected two people (55 and $76 \mathrm{yr}$ old). Cases for which the hour of occurrence were available are almost equally divided among unfavourable (night or afternoon: 6 of 10 cases) and favourable light conditions (daylight). All victims were men, and the average age was $43 \mathrm{yr}$. $50 \%$ of victims occurred along fast-flowing roads, and $30 \%$ on municipal roads $(30 \%)$.

Injured, reported in 31 records $(25 \%)$ (Table 3), were $84 \%$ motorists and $16 \%$ pedestrians. The most common cases $(64 \%)$ concerned motorists wounded from trauma in car accidents (mainly caused by urban flooding), followed by trauma suffered by pedestrians hit by objects driven by wind $(12 \%)$, and trauma affecting motorists in cars buried by landslide debris $(9 \%)$. Only three people affected by collapse were reported, two of whom were over $70 \mathrm{yr}$ old. According to the time of occurrence, available for 17 of the 31 cases, $59 \%$ of the cases occurred in night conditions. The number of men and women wounded (when these data were available) was similar (19 and 17, respectively). The highest number of cases occurred along municipal (39\% of records) and county roads (32\%).

People involved but not injured were reported in 85 records (67\%) (Table 4). A numerical value expressing people involved is available in $58 \%$ of these records, which include 522 people. For the remaining records (42\%), only qualitative descriptions are supplied (i.e. some people or many people involved). If we translate these frequency words into numbers, an estimate of the number of people involved can be obtained. Five people were assumed for cases that involved individuals described as "some people", and a value of 10 was assumed in cases described as "many people." The estimate of people involved in the remaining $42 \%$ of the cases is about 260 , and the total number of people involved 
Table 3. Cases of injured. For each record, the following data are reported: damaging agent,number of injured, road type $(\mathrm{H}=\mathrm{Highway}$; $\mathrm{S}=$ State road; $\mathrm{C}=$ County road; and $\mathrm{M}=$ Municipal road), time at which the damage occurred $(\mathrm{A}=$ afternoon, $\mathrm{M}=$ morning, $\mathrm{N}=$ night, $\mathrm{S}=$ sunrise $),(\mathrm{M}=$ male $; \mathrm{F}=$ female $)$, age $(\mathrm{Ad}=$ adult $\mathrm{Ch}=$ child $)$ and wounding circumstance.

\begin{tabular}{|c|c|c|c|c|c|c|c|c|c|}
\hline $\mathrm{N}$. & $\begin{array}{l}\text { Damaging } \\
\text { agent }\end{array}$ & $\begin{array}{l}\text { N. of } \\
\text { victims }\end{array}$ & $\begin{array}{l}\text { Road } \\
\text { type }\end{array}$ & $\begin{array}{l}\text { Hour } \\
\text { LT }\end{array}$ & Sex & Age & Wounding circumstance & Tot. & $\%$ \\
\hline 1 & Urban flooding & 5 & $\mathrm{~S}$ & $22: 30$ & - & - & & & \\
\hline 2 & Urban flooding & 2 & M & $14: 00$ & - & - & & & \\
\hline 3 & Urban flooding & 7 & $\mathrm{~S}$ & 20:00 & - & $1 \mathrm{Ad} 6 \mathrm{Ch}$ & & & \\
\hline 4 & Urban flooding & 1 & $\mathrm{~S}$ & A & $\mathrm{M}$ & 42 & & & \\
\hline 5 & Urban flooding & 4 & S & - & M & - & Trauma: motorist injured in a car accident & 82 & 64 \\
\hline 6 & Urban flooding & 1 & M & - & $\mathrm{F}$ & - & & & \\
\hline 7 & Urban flooding & 1 & M & _ & M & _- & & & \\
\hline 8 & Wind & 5 & $\mathrm{~S}$ & A & M & 14 & & & \\
\hline 9 & Flood & 42 & $\mathrm{C}$ & 10:00 & - & - & & & \\
\hline 10 & Landslide & 14 & $S$ & M & $12 \mathrm{~F} ; 2 \mathrm{M}$ & $15 \leftrightarrow 74$ & & & \\
\hline 11 & Landslide & 4 & $\mathrm{~S}$ & 19:00 & - & $2 \mathrm{Ad} 2 \mathrm{Ch}$ & & & \\
\hline 12 & Landslide & 1 & $\mathrm{C}$ & - & - & - & & & \\
\hline 13 & Landslide & 1 & $\mathrm{C}$ & 21:00 & - & Ad & Trauma: motorist injured in a car buried by landslide debris & 12 & 9 \\
\hline 14 & Landslide & 1 & M & - & M & - & & & \\
\hline 15 & Landslide & 5 & $\mathrm{H}$ & 21:00 & M & $59 ; 53 ; 33$ & & & \\
\hline 16 & Landslide & 1 & $\mathrm{~S}$ & - & - & - & & & \\
\hline 17 & Landslide & 1 & $\mathrm{C}$ & M & M & 82 & Trauma: motorist injured in a car hit by falling rocks & 3 & 2 \\
\hline 18 & Landslide & 1 & M & - & $\mathrm{F}$ & 20 & & & \\
\hline 19 & Flood & 1 & M & 08:00 & M & - & & & \\
\hline 20 & Landslide & 1 & $\mathrm{C}$ & - & M & - & Trauma suffered by a rescuer & 3 & 2 \\
\hline 21 & Landslide & 1 & $\mathrm{C}$ & - & M & - & & & \\
\hline 22 & Wind & 1 & M & - & $\mathrm{F}$ & - & Trauma: suffered by motorist hit by objects driven by wind & 2 & 2 \\
\hline 23 & Wind & 1 & M & - & M & 54 & & & \\
\hline 24 & Wind & 1 & M & $\mathrm{N}$ & M & 26 & Trauma: suffered by pedestrian hit by objects driven by wind & 16 & 12 \\
\hline 25 & Wind & 15 & M & $15: 00$ & - & - & & & \\
\hline 26 & Landslide & 1 & $\mathrm{C}$ & 19:00 & M & - & & & \\
\hline 27 & Flood & 3 & $\mathrm{C}$ & - & M & - & Trauma: motorist fell through a crack in the road & 7 & 5 \\
\hline 28 & Flood & 3 & $\mathrm{C}$ & $\mathrm{S}$ & $1 \mathrm{M} 2 \mathrm{~F}$ & - & & & \\
\hline 29 & Sea storm & 1 & M & - & M & - & Trauma: pedestrian hurt by sea waves & 1 & 1 \\
\hline 30 & Urban flooding & 2 & M & - & - & $>70$ & Collapse affecting motorist trapped in submerged cars & 2 & 2 \\
\hline \multirow[t]{2}{*}{31} & Landslide & 1 & $\mathrm{C}$ & 19:00 & M & - & Collapse affecting a rescuer & 1 & 1 \\
\hline & & & & & & & Total & 129 & 100 \\
\hline
\end{tabular}

can be roughly assessed as 782. People were involved more frequently on municipal (58\%) and state roads (21\%). Of these cases, $57 \%$ of the people involved were motorists rescued in cars submerged either by floods ( 215 people in 15 cases) or by urban flooding (203 people in 30 cases). Then, the average number of involved people is assessed as 7 for urban flooding and 14 for floods. The cases of people rescued from cars partially buried by landslides make up $29 \%$. Generally, these cases affected a small number of people, but in two cases (No. 61 and No. 69), the landslide occurrence involved several people. In the first case, on 5 November 2004, in the north sector of the region (Tarsia municipality), a landslide occurred at night just outside of a highway tunnel. A bus, hit by the landslide debris, stopped, thus causing several minor collisions without casualties. In the second case, on 11 December 2004, in the SW sector, three mudflows, which were triggered simultaneously along a narrow municipal road (Taurianova municipality), blocked several cars, causing an incident which involved 70 people in minor collisions without casualties.

\subsection{Temporal and spatial distribution of effects on people}

Victims were recorded in 5 of the $10 \mathrm{yr}$ analysed (2003, 2004, 2006, 2008 and 2009), while injured were recorded in all but 1 of the 10 analysed years (2005). Involved people were reported every year. 2008 and 2003 had the highest number of victims (4 and 3, respectively). The highest number of victims in a single case (3 people) occurred on 3 July 2006, when both flash floods and urban flooding affected the town of Vibo Valentia (SW middle sector). 
Table 4. Cases in which people were involved. For each record, the following data are reported: damaging agent, number of people involved, road type $(\mathrm{H}=$ Highway; $\mathrm{S}=$ State road; $\mathrm{C}=$ County road; and $\mathrm{M}=$ Municipal road), time at which the damage occurred (A= afternoon, $\mathrm{M}=$ morning, $\mathrm{N}=$ night, $\mathrm{S}=$ sunrise), sex of people involved, age of people involved (Ad= adult; $\mathrm{Ch}=$ child), and circumstance.

\begin{tabular}{|c|c|c|c|c|c|c|c|c|c|}
\hline $\mathrm{N}$. & $\begin{array}{l}\text { Damagingt } \\
\text { agent }\end{array}$ & $\begin{array}{l}\text { N. of } \\
\text { people }\end{array}$ & $\begin{array}{l}\text { Road } \\
\text { type }\end{array}$ & Hour & Sex & Age & Involvement circumstance & Tot. & $\%$ \\
\hline 1 & Urban flooding & 3 & M & - & - & - & & & \\
\hline 2 & Urban flooding & Some & M & A & - & - & & & \\
\hline 3 & Urban flooding & Some & M & - & - & - & & & \\
\hline 4 & Urban flooding & 2 & $\mathrm{~S}$ & - & - & - & & & \\
\hline 5 & Urban flooding & Some & $\mathrm{C}$ & - & - & - & & & \\
\hline 6 & Urban flooding & Many & M & - & - & - & & & \\
\hline 7 & Urban flooding & 2 & M & - & - & - & & & \\
\hline 8 & Urban flooding & Many & M & - & - & - & & & \\
\hline 9 & Urban flooding & Some & M & A & - & - & & & \\
\hline 10 & Urban flooding & 30 & $S$ & - & - & - & & & \\
\hline 11 & Urban flooding & Many & M & - & $\mathrm{F}$ & - & & & \\
\hline 12 & Urban flooding & 10 & $\mathrm{~S}$ & $\mathrm{~N}$ & - & - & & & \\
\hline 13 & Urban flooding & Some & $\mathrm{C}$ & - & - & - & & & \\
\hline 14 & Urban flooding & Some & $\mathrm{C}$ & - & - & - & & & \\
\hline 15 & Urban flooding & Some & $\mathrm{C}$ & - & - & - & & & \\
\hline 16 & Urban flooding & Many & $\mathrm{C}$ & - & - & - & & & \\
\hline 17 & Urban flooding & Some & M & M & - & - & & & \\
\hline 18 & Urban flooding & Some & M & - & - & - & & & \\
\hline 19 & Urban flooding & 1 & M & - & - & - & & & \\
\hline 20 & Urban flooding & Many & $\mathrm{S}$ & - & - & - & & & \\
\hline 21 & Urban flooding & Some & M & $\mathrm{N}$ & - & - & & & \\
\hline 22 & Urban flooding & Some & $\mathrm{S}$ & - & - & - & & & \\
\hline 23 & Urban flooding & Some & M & - & - & - & & & \\
\hline 24 & Urban flooding & Many & M & - & - & - & & & \\
\hline 25 & Urban flooding & 1 & M & - & $\mathrm{F}$ & - & & & \\
\hline 26 & Urban flooding & Many & M & - & - & - & Motorist rescued in submerged car & & \\
\hline 27 & Urban flooding & 1 & $\mathrm{C}$ & M & $\mathrm{F}$ & 74 & & 443 & 57 \\
\hline 28 & Urban flooding & Some & $\mathrm{S}$ & - & M & - & & & \\
\hline 29 & Urban flooding & Many & M & - & - & - & & & \\
\hline 30 & Urban flooding & Many & $\mathrm{C}$ & - & - & - & & & \\
\hline 31 & Flood & 1 & M & - & M & - & & & \\
\hline 32 & Flood & 58 & $\mathrm{~S}$ & - & - & - & & & \\
\hline 33 & Flood & 1 & M & - & M & - & & & \\
\hline 34 & Flood & 3 & M & - & - & - & & & \\
\hline 35 & Flood & Some & M & - & - & - & & & \\
\hline 36 & Flood & Many & $S$ & - & - & - & & & \\
\hline 37 & Flood & Many & $\mathrm{S}$ & $18: 30$ & - & - & & & \\
\hline 38 & Flood & 100 & $\mathrm{~S}$ & $10: 00$ & - & - & & & \\
\hline 39 & Flood & 2 & $\mathrm{C}$ & - & - & - & & & \\
\hline 40 & Flood & 5 & M & - & $2 \mathrm{~F} / 3 \mathrm{M}$ & - & & & \\
\hline 41 & Flood & Some & M & - & - & - & & & \\
\hline 42 & Flood & 4 & M & 8 & - & - & & & \\
\hline 43 & Flood & 1 & M & 0 & M & - & & & \\
\hline 44 & Flood & Many & $\mathrm{C}$ & - & - & - & & & \\
\hline 45 & Flood & Many & M & A & - & - & & & \\
\hline 46 & Sea storm & 3 & M & - & - & - & & & \\
\hline 47 & Sea storm & Many & M & - & - & - & & & \\
\hline 48 & Urban flooding & 2 & M & - & - & - & Motorist rescued in car submerged in underpasses & 13 & 1.7 \\
\hline 49 & Urban flooding & 1 & M & $\mathrm{N}$ & M & - & & & \\
\hline 50 & Urban flooding & Many & M & M & - & - & & & \\
\hline 51 & Flood & 2 & M & - & M & - & Motorist rescued when attempting cross a river & 4 & 0.5 \\
\hline 52 & Flood & 2 & M & 19:00 & - & - & & & \\
\hline 53 & Landslide & 1 & M & M & M & - & Motorist in car blocked by landslide & 3 & 0.4 \\
\hline 54 & Landslide & 1 & M & - & $\mathrm{F}$ & - & & & \\
\hline 55 & Landslide & 1 & $\mathrm{C}$ & M & M & - & & & \\
\hline 56 & Landslide & 1 & M & - & M & - & Motorist in car that fell in a crack & 2 & 0.3 \\
\hline 57 & Landslide & 1 & M & M & - & - & & & \\
\hline
\end{tabular}


Table 4. Continued.

\begin{tabular}{|c|c|c|c|c|c|c|c|c|c|}
\hline $\mathrm{N}$. & $\begin{array}{l}\text { Damaging circumstance } \\
\text { agent }\end{array}$ & $\begin{array}{l}\text { N. of } \\
\text { people }\end{array}$ & $\begin{array}{l}\text { Road } \\
\text { type }\end{array}$ & Hour & Sex & Age & Involvement & Tot. & $\%$ \\
\hline 58 & Landslide & 1 & $\mathrm{~S}$ & - & M & - & Motorist in car partially buried by a landslide & 230 & 29 \\
\hline 59 & Landslide & 1 & $\mathrm{~S}$ & $\mathrm{~N}$ & M & - & & & \\
\hline 60 & Landslide & Some & M & M & - & - & & & \\
\hline 61 & Landslide & 100 & $\mathrm{H}$ & $\mathrm{N}$ & - & - & & & \\
\hline 62 & Landslide & 2 & M & - & - & - & & & \\
\hline 63 & Landslide & 5 & M & 22 & - & - & & & \\
\hline 64 & Landslide & 32 & $\mathrm{C}$ & - & $\mathrm{M} / \mathrm{F}$ & $\mathrm{Ch}$ & & & \\
\hline 65 & Landslide & 1 & $\mathrm{C}$ & - & M & - & & & \\
\hline 66 & Landslide & Some & $\mathrm{C}$ & - & - & - & & & \\
\hline 67 & Landslide & 1 & M & - & M & - & & & \\
\hline 68 & Landslide & 1 & $\mathrm{~S}$ & M & M & 20 & & & \\
\hline 69 & Landslide & 70 & M & 14 & - & - & & & \\
\hline 70 & Landslide & 1 & $\mathrm{C}$ & 14 & - & - & & & \\
\hline 71 & Landslide & 1 & M & - & M & - & & & \\
\hline 72 & Landslide & 3 & $\mathrm{C}$ & - & - & - & & & \\
\hline 73 & Landslide & 1 & M & - & M & - & & & \\
\hline 74 & Landslide & 1 & M & - & - & - & Motorist in car touched by falling rocks & 15 & 1.9 \\
\hline 75 & Landslide & Some & $\mathrm{C}$ & - & - & - & & & \\
\hline 76 & Landslide & 2 & M & - & - & - & & & \\
\hline 77 & Landslide & 1 & $\mathrm{C}$ & - & M & - & & & \\
\hline 78 & Landslide & 1 & M & M & $\mathrm{F}$ & - & & & \\
\hline 79 & Landslide & Some & $\mathrm{S}$ & A & - & - & & & \\
\hline 80 & Wind & 15 & $\mathrm{~S}$ & M & - & $<14$ & Motorist involved in car accident & 26 & 3.3 \\
\hline 81 & Wind & Many & $\mathrm{S}$ & - & M & - & & & \\
\hline 82 & Wind & 1 & $\mathrm{~S}$ & - & - & - & & & \\
\hline 83 & Wind & 1 & M & - & - & - & Motorist in car hit by objects driven by wind & 46 & 5.9 \\
\hline 84 & Wind & Some & $\mathrm{C}$ & $\mathrm{N}$ & $\mathrm{M} / \mathrm{F}$ & - & & & \\
\hline \multirow[t]{2}{*}{85} & Wind & 40 & M & - & - & - & & & \\
\hline & & & & & & & Total estimated & 782 & 100 \\
\hline
\end{tabular}

The highest number of injured in single events occurred in 2006, 2007, and 2001. In 2006, 42 injured were recorded because of the abovementioned case of Vibo Valentia. On 12 May 2001, in the SW sector, a rapid earth flow hit a state road (near Scilla), causing car accidents with 14 injured. During the case of 19 May 2007, a windstorm wounded 15 people, who were hit by wind-driven objects in the town of Lametia Terme (mid-western sector). Wind speed data are scarce throughout the region, but Lametia Terme is close to the main regional airport, so wind data are constantly collected. On 19 May, the maximum value of wind velocity was $25.9 \mathrm{~km} \mathrm{~h}^{-1}$, whereas the mean value assessed for the month of May, based on $32 \mathrm{yr}$ of observation, is $10 \mathrm{~km} \mathrm{~h}^{-1}$ (http://www.ilmeteo.it/portale/).

People involved in damaging situations were recorded mainly in 2004, 2003, and 2008. The high number in 2004 includes 19 cases, one of which involved approximately 100 people (the case of Tarsia). The high value of 2003 is related to a flood involving 58 people that affected a state road near Cropani (NE sector).
By sorting data according to damaging agents (Fig. 2), it can be determined that the widespread regional distributions concern to urban flooding and landslides. In both these maps, the central sector is the only part that has not recorded effects. Urban flooding mainly affected both the state road crossing the centre of the region and the state road running along the east coast. In the map of landslides, the injured are the majority, and they are mainly concentrated in the south and centralwestern sectors. The wind effects are mainly located in the central-southern sector, while the storm surge effects are limited to the west coast.

A lower concentration of victims and injured characterizes the NE sector, where damage occurrences were mainly located along the main state road, which runs parallel to the coast (Fig. 3). The inner mountainous sectors, characterised by low population density, did not present damage occurrences.

\subsection{Rainfall analysis}

Starting from 126 cases in which people were involved, we eliminated the cases of damage caused either by wind or 
Table 5. Main features of rainfall events causing damage to people along the road network of Calabria in the study period. The asterisk is used to denote average values.

\begin{tabular}{|c|c|c|c|c|c|}
\hline Group & 1 & 2 & 3 & 4 & \\
\hline Months of occurrence & Aug-Oct & Nov-Jan & Feb-Apr & May-Jul & Total \\
\hline Number of events & 16 & 63 & 8 & 11 & 98 \\
\hline Percentage of the events & 16 & 64 & 8 & 11 & 100 \\
\hline Landslide (No. of cases) & 0 & 29 & 2 & 1 & 32 \\
\hline Flood (No. of cases) & 3 & 16 & 2 & 4 & 25 \\
\hline Urban flooding (No. of cases) & 13 & 18 & 4 & 6 & 41 \\
\hline Total & 16 & 63 & 8 & 11 & 98 \\
\hline Landslide $(\%)$ & 0 & 46 & 25 & 9 & \\
\hline Flood $(\%)$ & 19 & 25 & 25 & 36 & \\
\hline Urban flooding (\%) & 81 & 29 & 50 & 55 & \\
\hline Total & 100 & 100 & 100 & 100 & \\
\hline Cases with victims & 0 & 7 & 1 & 1 & 9 \\
\hline Cases with injured & 2 & 16 & 0 & 3 & 21 \\
\hline Cases with involved & 14 & 40 & 7 & 7 & 68 \\
\hline Total & 16 & 63 & 8 & 11 & 98 \\
\hline Cases with victims (\%) & 0 & 11 & 13 & 9 & \\
\hline Cases with injured (\%) & 13 & 25 & 0 & 27 & \\
\hline Cases with involved (\%) & 88 & 63 & 88 & 64 & \\
\hline Total & 100 & 100 & 100 & 100 & \\
\hline Monthly rainfall* & 94 & 110 & 52 & 114 & \\
\hline Regional monthly rainfall & 55 & 98 & 69 & 32 & \\
\hline Daily rainfall* & 51 & 73 & 40 & 103 & \\
\hline Number of monthly daily rainfall* & 9 & 14 & 11 & 7 & \\
\hline Rainfall event duration (h)* & 6 & 13 & 11 & 6 & \\
\hline Max intensity: $1 \mathrm{~h} *$ & 28 & 20 & 10 & 51 & \\
\hline Max intensity: $30 \mathrm{~min} *$ & 19 & 13 & 7 & 34 & \\
\hline Max intensity: $10 \mathrm{~min} *$ & 11 & 6 & 5 & 16 & \\
\hline
\end{tabular}

storm surges, and the cases for which rainfall data recorded at raingauges of the hit areas were unavailable. For the remaining 98 cases, we collected the rainfall of different durations: (a) monthly rainfall of the month in which the damage occurred, (b) daily rainfall of the day on which the damage occurred, and (c) the maximum 60-min rainfall intensity recorded during that day. For 57 of these cases, even subhourly intensities were available, and thus we collected the maximum values for 10- and 30-min, recorded during the day on which the damage occurred, assuming that maximum values of rainfall intensities can be related to the triggering of damaging agents.

According to the months of occurrence, we sorted the events in groups: group 1: August-October; group 2: November-January; group 3: February-April; group 4: May-July (Table 5). The widest percentage of events (64\%) occurred in group 2, and the lowest in group $3(8 \%)$.
Landslides were most frequent between November and January (46\%); floods were abundant in all the groups, with percentage increasing from group $1(19 \%)$ to group $4(36 \%)$; urban flooding was the majority in both groups $1(81 \%)$ and $4(55 \%)$.

In all the groups, the majority of cases concern people involved but not hurt; cases with injured reach values greater than $20 \%$ for groups $2(25 \%)$ and $4(27 \%)$; cases with victims represent about $10 \%$ in all the groups except in group 1 , in which there were no victims.

By using the raingauges of the affected areas and the months in which damage occurred, we assessed the mean values of monthly rainfall, and compared these values to the average monthly rainfall of the same months obtained using all the regional raingauges for the period 1921-2009. For groups 1 and 4, the assessed values are considerably higher than the regional average: for group 1, this value is $94 \mathrm{~mm}$, 


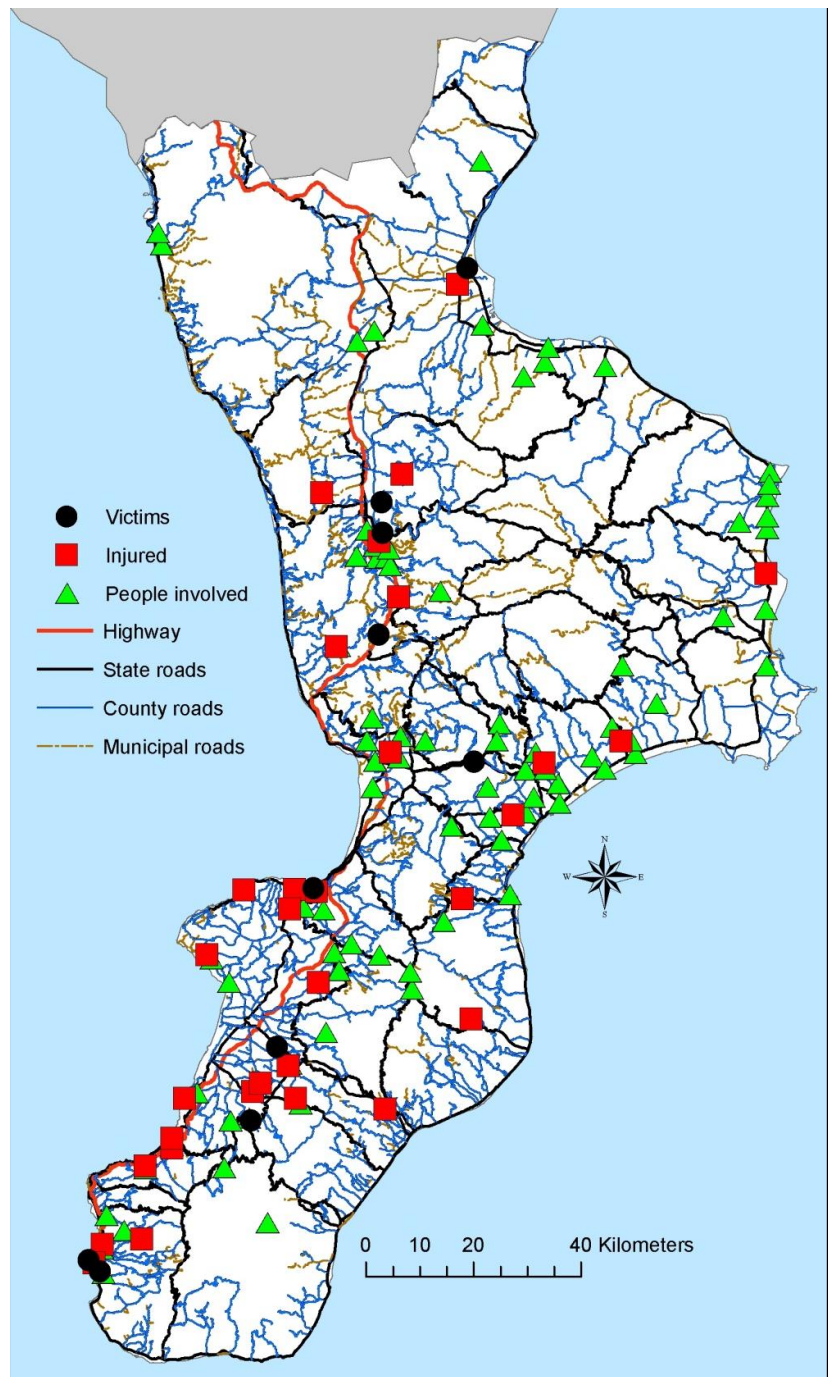

Fig. 3. Localisation of damage to people along the Calabria road network: symbols are explained in the legends.

against an average of $55 \mathrm{~mm}$, and for group 4, the value is $114 \mathrm{~mm}$, against a regional average of $32 \mathrm{~mm}$ (Table 5). This difference is less significant for group $2(110 \mathrm{~mm}$ against $98 \mathrm{~mm}$ ), while for group 3, this value $(52 \mathrm{~mm})$ is lower than the regional mean value $(69 \mathrm{~mm})$. Actually, the events of groups 2 and 3 occurred in winter months characterised by ordinary values of monthly rainfall; on the contrary, during spring and summer, the events occurred in unusually rainy months.

Analysing the number of rainy days of the months in which damage occurred, it can be noticed that summer and spring events are more concentrated: the average number of rainy days in those months was lower ( 9 and 7 , for groups 1 and 4, respectively) than in the case of winter months (14 and 11 for groups 2 and 3, respectively). Even the duration of rainfall events (that is the number of continuous rainy hours during which the effects occurred) confirms the predominant

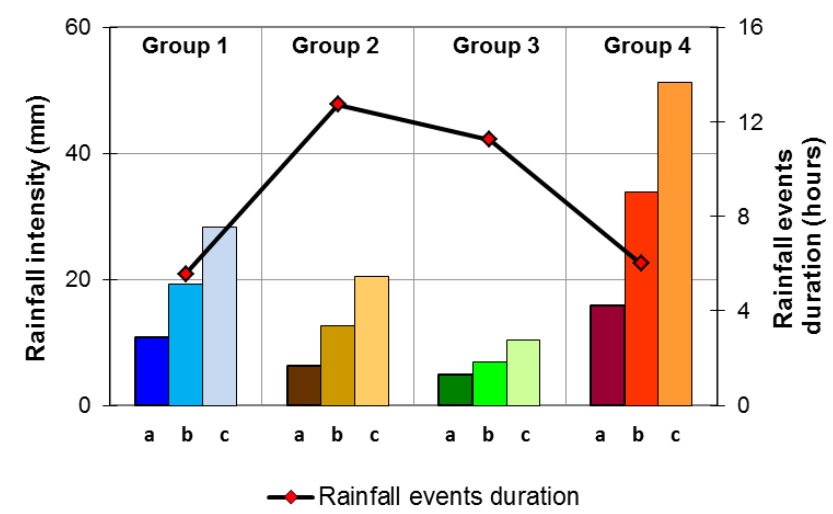

Fig. 4. Rainfall intensities and duration of rainfall events of the different groups. On the x-axis, a: 10-min, b: 30-min and c: 60-min rainfall intensity, for the events of the groups indicated on top of the diagram. Rainfall intensities are reported on the left Y-axis, and duration of the events are indicated on the right Y-axis.

"flash" character of the events of both groups 1 and 4: on the average, events of both spring and summer months are shorter $(6 \mathrm{~h})$ when compared to the events of winter months (13 and $11 \mathrm{~h}$ ). In addition, mean values of hourly and subhourly rainfall intensities are the greatest recorded (Fig. 4): the highest mean values pertain to the group 4 (51, 34 and $16 \mathrm{~mm}$, for 60,30 and $10 \mathrm{~min}$, respectively).

Thus, between May and July (group 4), short duration/high intensity rainfall triggered urban flooding and floods which caused injured and involved people, and more rarely victims. Lower rainfall intensities characterised the events of group 1 (August-October), which mainly caused urban flooding with no victims and numerous involved people. Between November and April (groups 2 and 3) the events were more frequent, showing longer durations and lower mean rainfall intensities. The prevailing phenomena were landslides (group 2) and floods (group 3): the highest number of cases with victims, mainly related to floods and urban flooding, occurred in group 2.

By sorting the cases according to the type of damaging agent, further details can be noticed. In Fig. 5, the diagram of floods contains 20 cases, $65 \%$ of which occurred between November and January. $50 \%$ of the cases were related to daily rainfall lower than $50 \mathrm{~mm}$, and the mode of daily rainfall is 45.8. Monthly rainfall, except for two cases which occurred in July (No. 5) and August (No. 12), ranges between $192 \mathrm{~mm}$ and $410 \mathrm{~mm}$. 60-min rainfall ranges from $5 \mathrm{~mm}$ to a maximum value of $105 \mathrm{~mm}$, recorded in July (No. 20, Vibo Valentia case). No direct relationship between rainfall and damage to people can be highlighted: victims occurred in cases of flash floods, as No. 20, but even in cases not classifiable as flash floods, characterised by low 60-min intensity and high monthly intensity (Nos. 2, 9, 11 and 19). 

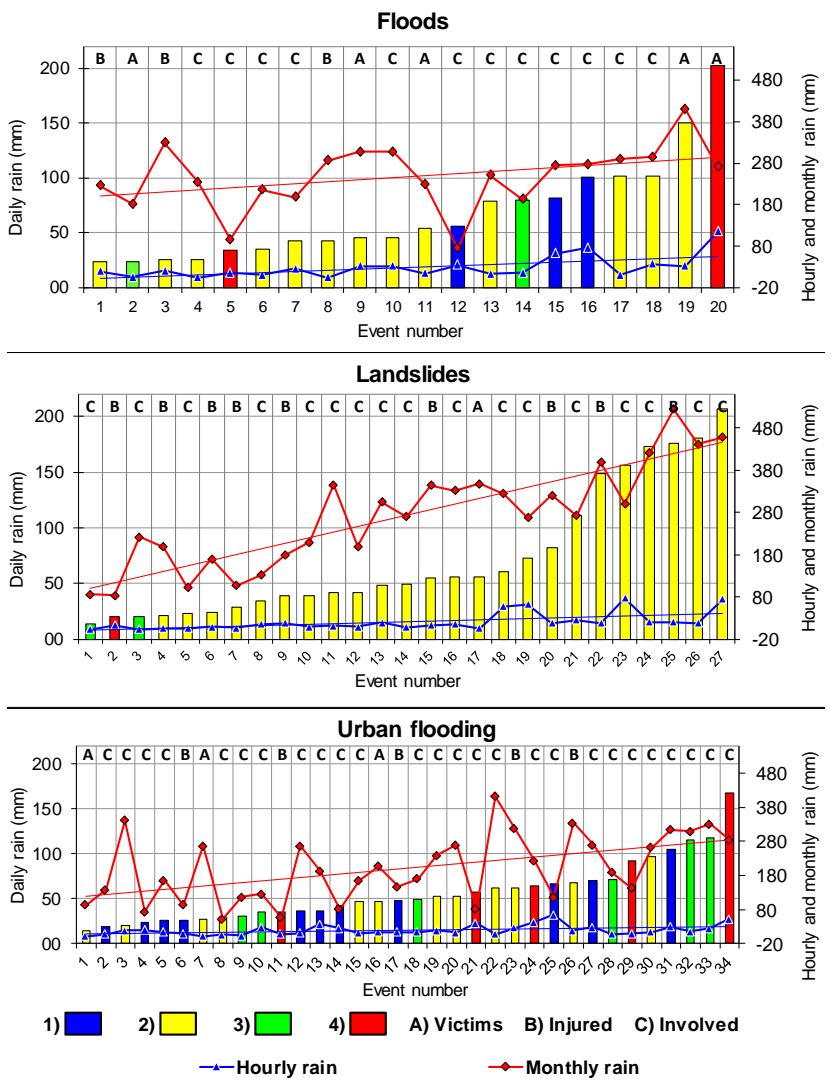

Fig. 5. Each diagram concerns a type of damaging agent. The events, identified by the number on the $\mathrm{x}$-axis, have been sorted according to increasing daily rainfall and the bars representing daily rainfall have been coloured according to the months of occurrence (blue: August-October; yellow: November-January; green: February-April; red: May-July). On top of each diagram, the types of damage to people recorded in each event have been indicated by letters: occurrence of victims (A), injured (B), and involved people C). Hourly and monthly rain are also shown.

The diagram of landslides includes 27 cases: $89 \%$ occurred between November and January. Daily rainfall varies between 13 and $206 \mathrm{~mm}$ and shows a mode of 41.4. The range of monthly rainfalls, from 82 to $524 \mathrm{~mm}$, is wider than in the case of floods, while 60-min rainfall ranges between 3 and $77 \mathrm{~mm}$. Only in one case (No. 17) victims occurred, while in $33 \%$ of cases, injured were reported.

The diagram of urban flooding contains 34 cases and it seems different from the previous two because: (a) events of all the groups are included, even if groups $2(44 \%)$ and $1(32 \%)$ are more abundant; (b) daily rainfall varies in a range $(14 \div 168 \mathrm{~mm})$ lower than in the cases of both floods and landslides, and its mode is lower (26); (c) monthly rainfall, on the average, is lower than in the former cases $(51 \div 411 \mathrm{~mm})$. The cases in which victims were reported (Nos. 1, 7 and 16) occurred between November and January.

\section{Discussion}

In the study period, the motorists represent the totality of the victims, $84 \%$ of the people injured and the total of people involved. The pedestrians injured were rescuers or people hit by objects hurled by wind. All victims were men, and the average age was $43 \mathrm{yr}$. This value is similar to the assessment obtained by Ruin et al. (2008) during a flash flood in Southern France; the other articles analysing flood victims (Table 1) do not supply values to be compared with our estimate, and among the consulted literature, no data about average age of victims caused by the other damaging agents were available.

The most common cause of death was drowning caused by floods when victims were trying to abandon their vehicles (46\%), as highlighted in other areas (Rappaport, 2000). Also, $23 \%$ of victims died by trauma suffered in car accidents caused by urban flooding. As pointed out in literature, the loss of life caused by floods is influenced by motorists' reckless behaviour (Jonkman and Vrijling, 2008). In case No. 7 of Table 2, the death recorded was drowning during an attempt to cross a flooded makeshift crossing. In No. 9, a man was rescued in a similar circumstance but died soon after due to collapse. In both cases, the fatalities occurred on the way to the victim's house, thus confirming that the sense of security related to the familiarity of the road increases a driver's hazardous behaviours (Maples and Tiefenbacher, 2009).

While the majority of victims occurred along state roads, the injured and people involved were mainly recorded along municipal roads $(51 \%)$. Municipal roads are the weakest part of the network, often crossing landslides or flood prone areas and frequently characterised by not modern construction standards. Both the ordinary maintenance and the emergency works are performed at the expense of the traversed municipalities, and the effectiveness of these works depends strictly on the wealth of each municipality. Thus, the effects of rainfall on these roads can be amplified by weakness points which can be related either to environmental constraints (the necessity of passing through landslide/floodprone areas) or to incorrect/inadequate works realisation.

The analysis of circumstances concerning injured and involved people assumes a certain importance if they are considered cases of "lucky escapes". The high number of motorists rescued in submerged cars is an indication of lack of awareness of the danger; in none of the cases did this underestimation of risk involve pedestrians. This confirms that the improved safety of automobiles led to a wrong belief of motorist invulnerability, leading to irresponsible behaviours (Maples and Tiefenbacher, 2009). In contrast, in cases of people involved in landslide events, it seems that after realising the potential risk, people behaved to avoid negative consequences, such as changing direction or abandoning the car. Victims only occurred in one case (No. 4 in Table 2), 
at night, and on a fast flowing road (highway). In this case, the motorist did not have time to realise that a landslide was occurring.

Collected data do not show a straightforward relationship between rainfall characteristics and severity of damage to people, even if qualitative considerations can be done. Between May and July (group 4), the events occurring in months characterised by unusually high monthly rainfall: on the average rain was concentrated in 7 rainy days, during which the most intense rain episode, lasting on the average $6 \mathrm{~h}$, presented the highest hourly and sub-hourly rainfall intensities recorded. Urban flooding and floods were the most common damaging agents; injured, involved people and more rarely victims were reported. The events occurred between August and October (group 1) show similar characteristics even if hourly and sub-hourly rainfall intensities were lower than in the former case.

Events were more frequent between November and April (groups 2 and 3). Rainfall presented longer durations $(11 \div 14$ rainy days); maximum values of hourly and subhourly rainfall occurred in $11-13 \mathrm{~h}$ of continued rain, and were lower than those recorded between May and October (Table 5). Landslides were the most frequent damaging agents but the highest number of cases with victims was mainly related to floods and urban flooding and occurred between November and January.

\section{Conclusions}

An analysis of damage to people during bad weather periods along the road network of a region of southern Italy was conducted by using newspaper data. Damaging agents were sorted into five types: flood, urban flooding, landslide, wind, and storm surge. During a study period of $10 \mathrm{yr}, 126$ cases of damage to people were reported as follows: 13 victims, 129 injured and 782 people involved but not injured.

In terms of agents causing victims, flood was the most dangerous (5 cases with victims), followed by urban flooding ( 3 cases), landslide (1 case) and wind ( 1 case). Floods occurred mainly between November and January (65\%) and flash floods between May and October: in both cases victims occurred. Landslides were mainly concentrated between November and January, while urban flooding occurred in each period of the year.

Motorists were more frequently involved than pedestrians in damaging situations; only a few cases involved pedestrians injured in attempted rescues or people hit by objects hurled by the wind. All victims were men, and the average age was $43 \mathrm{yr}$. The primary cause of death was drowning caused by floods, and the second one was trauma suffered in car accidents caused by urban flooding. Reckless behaviours were detected among victims, injured, and involved people in cases of floods, and the high number of motorists rescued from submerged cars indicates a lack of awareness of flood risk, often increased by the sense of security related to the familiarity of the road. In contrast, in cases of landslides, when there was enough time to realise the potential risk, people behaved to avoid negative consequences, such as changing direction or abandoning the car. $50 \%$ of victims occurred along the state roads and the highway: this could be related to the high speed limit in force on these roads, which reduces the time motorists have to react to unexpected situations. The information gathered on people's behaviour can contribute to the understanding of damaging circumstances and can help promote information campaigns that aim to encourage more responsible and self-protective behaviour.

The mapping of damaging effects pointed out the regional sectors for which the high frequency of damaging events suggests planning further in-depth examinations; based on these results, both the potential construction faults and local regulator interventions that might change the future incidences can be individuated.

The major constraint of the approach depends on the level of detail of newspaper data, which is related to the severity of the events: data concerning less severe cases are not very detailed and this can cause heterogeneity in data quality and lack of information such as the number of people involved or age, gender, hour of the events, which can be used in statistical analysis. To bypass these difficulties, future surveys should focus on regional sectors for which ancillary damage data can provide the lacking information, thus allowing statistical data elaborations.

Acknowledgements. The authors thank the referees, for their suggestions which greatly improved the paper and Tommaso Caloiero for the support he provided in gathering rainfall data.

Edited by: A. Bartzokas

Reviewed by: A. N. Skouloudis, M. C. Llasat, and two

other anonymous referees

\section{References}

Adhikari, P., Hong, Y., Douglas, K. R., Kirschbaum, D. B., and Gourley, J.: A digitized global flood inventory (1998-2008): compilation and preliminary results, Nat. Hazard, 55, 405-422, 2010.

Agasse, E.: Flooding during the 17th to 20th centuries in Normandy (western France): methodology and use of historical data, in: Palaeofloods, Historical Floods and Climatic Variability: Applications in Flood Risk Assessment, edited by: Thorndycraft, V. R., Benito, G., Barriendos, M., and Llasat, M. C., Proceedings of the PHEFRA Workshop, Barcelona, 16-19th October, 2002, 99-105, 2003.

Ashley, S. T. and Ashley, W. S.: Flood Fatalities in the United States, J. Appl. Meteorol. Climatol., 47, 805-818, 2008.

Ashley, W. S. and Black, A. W.: Fatalities Associated with Nonconvective High-Wind Events in the United States, J. Appl. Meteorol. Climatol., 47, 717-725, 2008.

Barnikel, F. and Becht, M.: A historical analysis of hazardous events in the Alps - the case of Hindelang (Bavaria, Germany), 
Nat. Hazards Earth Syst. Sci., 3, 625-635, doi:10.5194/nhess-3625-2003, 2003.

Blong, R.: A review of damage intensity scales, Nat. Hazards, 29, 57-76, 2003.

Boholm, M.: Risk and Causality in Newspaper Reporting, Risk Analysis, 29, 1566-1577, doi:10.1111/j.1539-6924.2009.01296, 2009.

Budetta, P.: Risk assessment from debris flows in pyroclastic deposits along a motorway, Italy, Bull. Eng. Geol. Env., 61, 293$301,2002$.

Coates, L.: Flood fatalities in Australia, 1788-1996, Australian Geographer, 30, 391-408, 1999.

Copien, C., Frank, C., and Becht, M.: Natural hazards in the Bavarian Alps: a historical approach to risk assessment, Nat. Hazards, 45, 173-181, doi:10.1007/s11069-007-9166-6, 2008.

Crozier, M. J.: Multiple-occurrence regional landslide events in New Zealand: Hazard management issues, Landslides, 2, 247 256, 2005.

Cuesta, M. J. D., Sanchez, M. J., and Garcia, A. R.: Press archives as temporal records of landslides in the North of Spain: relationships between rainfall and instability slope events, Geomorphology, 30, 125-132, 1999.

Devoli, G., Morales, A., and Høeg, K.: Historical landslides in Nicaragua-collection and analysis of data, Landslides, 4, 5-18, 2007.

Drobot, S. D., Gruntfest, E., Barnes, L., Benight, C., Schultz, D., and Demuth, J.: Diving under the influence of weather: perceptions of flash floods and vehicle safety, 16th Conference on Applied Climatology, 4 pp., 2007.

FitzGerald, G., Du, W., Jamal, A., Clark, M., and Hou, X.: Flood fatalities in contemporary Australia (1997-2008), Emergency Medicine Australasia, 22, 180-186, 2010.

Hilker, N., Badoux, A., and Hegg, C.: The Swiss flood and landslide damage database 1972-2007, Nat. Hazards Earth Syst. Sci., 9, 913-925, doi:10.5194/nhess-9-913-2009, 2009.

Irigaray, C., Lamas, F., El Hamdouni, R., Fernàndez, T., and Chacòn, J.: The importance of the precipitation and the susceptibility of the slopes for the triggering of landslides along the roads, Nat. Hazards, 21, 65-81, 2000.

Jaiswal, P., Westen, C. J. van., and Jetten, V.: Quantitative assessment of direct and indirect landslide risk along transportation lines in southern India, Nat. Hazards Earth Syst. Sci., 10, 12531267, doi:10.5194/nhess-10-1253-2010, 2010.

Jonkman, S. and Kelman, I.: An analysis of the causes and circumstances of flood disaster deaths, Disasters, 29, 75-97, 2005.

Jonkman, S. N. and Vrijling, J. K.: Loss of life due to foods, J. Flood Risk Manage., 1, 43-56, 2008.

Kuriakose, S. L., Sankar, G., and Muraleedharan, C.: History of landslide susceptibility and a chorology of landslide-prone areas in the Western Ghats of Kerala, India. Environ. Geol., 57, 1553$1568,2009$.

Llasat, M. C., Llasat-Botija, M., Barnolas, M., López, L., and Altava-Ortiz, V.: An analysis of the evolution of hydrometeorological extremes in newspapers: the case of Catalonia, 1982-2006, Nat. Hazards Earth Syst. Sci., 9, 1201-1212, doi:10.5194/nhess-9-1201-2009, 2009.

Maples, L. Z. and Tiefenbacher, J. P.: Landscape, development, technology and drivers: The geography of drownings associated with automobiles in Texas floods, 1950-2004, Appl. Geogr., 29,
224-234, 2009.

Petrucci, O. and Polemio, M.: The role of meteorological and climatic conditions in the occurrence of damaging hydro-geologic events in Southern Italy, Nat. Hazards Earth Syst. Sci., 9, 105118, doi:10.5194/nhess-9-105-2009, 2009.

Petrucci, O. and Versace, P.: Frane e alluvioni in provincia di Cosenza agli inizi del '900: ricerche storiche nella documentazione del Genio Civile - I Quaderno dell'Osservatorio di Documentazione del Dipartimento di Difesa del Suolo (UNICAL) Bios, Cosenza (Italy) 172 pp., available at: http://books.google. it/, 2005.

Petrucci, O. and Versace, P.: Frane e alluvioni in provincia di Cosenza tra il 1930 e il 1950: ricerche storiche nella documentazione del Genio Civile - II Quaderno dell'Osservatorio di Documentazione del Dipartimento di Difesa del Suolo (UNICAL) Pubbl. GNDCI N. 2913, Nuova Bios, Cosenza, ISBN 978-886093-029, 247 pp., available at: http://books.google.it/, 2007.

Petrucci, O., Pasqua, A. A., and Gullà, G.: Landslide damage assessment using the Support Analysis Framework (SAF): the 2009 landsliding event in Calabria (Italy), Adv. Geosci., 26, 13 17, doi:10.5194/adgeo-26-13-2010, 2010.

Petrucci, O., Polemio, M., and Pasqua, A. A.: Analysis of Damaging Hydrogeological Events: the case of the Calabria Region (Southern Italy), Environ. Manage., 25, 483-495, 2008.

Petrucci, O., Versace, P., and Pasqua, A. A.: Frane e alluvioni in provincia di Cosenza fra il 1951 ed il 1960: ricerche storiche nella documentazione del Genio Civile - III Quaderno dell'Osservatorio di Documentazione del Dipartimento di Difesa del Suolo (UNICAL), Rubbettino, Soveria Mannelli (Italy), 316 pp., available at: http://books.google.it/, 2009.

Rappaport, E. N.: Loss of Life in the United States Associated with Recent Atlantic Tropical Cyclones, B. Am. Meteorol. Soc., 81, 2065-2073, 2000.

Ruin, I., Creutin, J. D., Anquetin, S., and Lutoff, C.: Human exposure to flash-floods - relation between flood parameters and human vulnerability during a storm of September 2002 in Southern France, J. Hydrol., 361, 199-213, 2008.

Salvati, P., Bianchi, C., Rossi, M., and Guzzetti, F.: Societal landslide and flood risk in Italy, Nat. Hazards Earth Syst. Sci., 10, 465-483, doi:10.5194/nhess-10-465-2010, 2010.

Solana, M. C. and Kilburn, C. R. J.: Public awareness of landslide hazards: the Barranco de Tirajana, Gran Canaria, Spain, Geomorphology, 54, 39-48, 2003.

Van Westen, C. J., Asch, T. W. J., and Soeters, R.: Landslide hazard and risk zonation-why is it still so difficult?, Bull. Eng. Geol. Env., 65, 67-184, 2006.

Wilson, R. A., Moon, A. T., Hendrickx, M., and Stewart, I. E.: Application of quantitative risk assessment to the Lowrence Hargrave Drive Project, New South Wales, Australia, available at: http://www.coffey.com/Uploads/Documents/ quantitative-risk_20070125032650.pdf, last access: 29 September 2010, 2005.

Zêzere, J. L., Oliveira, S. C., Garcia, R. A. C., and Reis, E.: Landslide risk analysis in the area North of Lisbon (Portugal): evaluation of direct and indirect costs resulting from a motorway disruption by slope movements, Landslides, 4, 123-136, 2007. 